\title{
Досвід тестування фрізичної підготовленості учнівської молоді України і Китайської Народної Республіки
}

\section{Сергій Трачук, Ген Янь, Інна Мамедова}

\section{Національний університет фрізичного виховання і спорту України, Київ, Україна}

Анотація. Фізична підготовка учнівської молоді як процес і її результат - ффізична підготовленість - є загальновизнаним ключовим показником благополуччя дітей і підлітків, і важливим показником здоров'я у подальшому житті в сучасних концепціях розвитку розвинених країн. Мета. Узагальнити і зіставити досвід тестування фізичної підготовленості учнівської молоді України і Китайської Народної Республіки. Методи. Теоретичний аналіз і узагальнення даних літературних джерел, контент-аналіз нормативних і програмно-методичних документів, компаративний метод зіставлення та аналізу зарубіжного й вітчизняного досвіду, логіко-теоретичний аналіз, історичний аналіз. Результати. У ході дослідження встановлено значення та специфіку тестів для оцінки рівня фізичної підготовленості учнівської молоді у системі фізичного виховання України та КНР. Виявлено типові вправи, що використовуються в процесі тестування рівня ффізичної підготовленості учнів. Загалом в кожній із систем оцінки фрізичної підготовленості чітко простежуються визначені основні маркери, що загалом і визначають рівень підготовленості. У системах тестування фізичної підготовленості учнівської молоді України і КНР відображено загальні підходи до організації та форматування тестових нормативів фрізичної підготовленості, які дозволяють оцінити основні рухові якості учнів, а в практиці КНР система доповнена індексом маси тіла й оцінкою функціональних можливості дихальної системи. Узагальнюючи дані тестування двох країн, необхідно зазначити, що рівень фізичної підготовленості потребує адекватної реакції в прийняті рішень уповноважених органів влади, саме в ключовому аспекті забезпечення самого процесу фрізичної підготовки (створення належних умов, інфраструктури тощо).

Ключові слова: фізична підготовленість, тестування, фрізичне виховання, школярі.

\section{Serhii Trachuk, Gen Yan, Inna Mamedova}

\section{EXPERIENCE OF TESTING PHYSICAL FITNESS OF STUDENT YOUTH OF UKRAINE AND PEOPLE'S REPUBLIC OF CHINA}

Abstract. Physical preparation of student youth as a process and its result - physical fitness - is a widely recognized key index of the well-being of children and adolescents, and an important indicator of health during later life in modern concepts of development of developed countries Objective. To generalize and compare the experience of testing the physical fitness of student youth of Ukraine and the People's Republic of China. Methods. Theoretical analysis and generalization of data from literature sources, content analysis of normative and programmethodical documents, comparative method of comparison and analysis of foreign and domestic experience, logical-theoretical analysis, historical analysis. Results. The study established the importance and specificity of tests to assess the level of physical fitness of students in the system of physical education in Ukraine and China. Typical exercises used in the process of testing the level of physical fitness of students are identified. In general, in each of the systems of physical fitness assessment, certain basic markers are clearly traced, which in general determine the leve of fitness. The systems of testing the physical fitness of students in Ukraine and China reflect the general approaches to the organization and formatting of test standards of physical fitness, which allow assessing the basic motor skills of students. In PRC the system is supplemented by body mass index and assessment of respiratory system functional capacities. Summarizing the testing data of the two countries, it should be noted that the level of physical fitness requires an adequate response to the decisions of the authorities, namely in the key aspect of ensuring the process of physical training itself (creating appropriate conditions, infrastructure, etc.)

Keywords: physical fitness, testing, physical education, school children.

Trachuk S, Gen Yan, Mamedova I. Experience of testing physical fitness of student youth of Ukraine and People's Republic of China. Theory and Methods of Physical education and sports. 2020; 4: 96-100 DOI: 10.32652/tmfvs.2020.4.96-100
Трачук С, Ген Янь, Мамедова І. Досвід тестування фрізичної підготовленості учнівської молоді України і Китайської Народної Республіки. Теорія і методика фрізичного виховання і спорту. 2020; 4: $96-100$

DOI: 10.32652/tmfvs.2020.4.96-100
Вступ. Серед стратегічних державних завдань удосконалення системи фрізичного виховання визначають їі орієнтацію програмно-нормативних основ на комплекс показників, що характеризують обсяг щоденної рухової активності, рівень фрізичного розвитку, стан фрункціональних систем організму, фрізичної роботоздатності та фрізичної підготовленості $[1,3,6]$.

Якість фрізичної підготовленості населення і її контроль є невід'ємною складовою фрізичного виховання як соціальної підсистеми суспільства і виконує важливі педагогічні, політичні та соціальні функції й тісно пов'язана 3 освітою, охороною здоров'я, військовою справою, матеріальним виробництвом, культурою, наукою [2, 3].

Згідно з твердженнями науковців, забезпечення реалізації оздоровчої функції фрізичного виховання різних груп населення вимагає, перш за все, наявності надійної, інформативної моніторингової системи $[12,13,17]$.

На сьогодні накопичено великий обсяг емпіричного знання, проведено серйозні теоретичні узагальнення [7, 11-13].

Проте недостатньою мірою подаються аналітично-порівняльні точки зору науковців на складові процесу фрізичного виховання в різних країнах, зокрема й у контексті висвітлення особливостей конструювання тестів для оцінювання фрізичної підготовленості.

Роботу виконано відповідно до теми Зведеного плану НДР Міністерства освіти України на 2021-2025 рр. 3.1 «Удосконалення системи педагогічного контролю фрізичної підготовленості дітей, підлітків і молоді в закладах освіти».

Мета дослідження - узагальнити і зіставити досвід тестування фрізичної підготовленості учнівської молоді України і Китайської Народної Республіки (КНР).

Методи дослідження: теоретичний аналіз і узагальнення даних літератур- 
Т а б л и ц я 1. Тести для проведення щорічного оцінювання фрізичної підготовленості школярів України

\begin{tabular}{|c|c|}
\hline Вікова категорія & Тести \\
\hline $\begin{array}{l}\text { Школярі і студенти } \\
\text { (8-20 років) }\end{array}$ & $\begin{array}{l}\text { 1. Підтягування на перекладині, разів або Стрибок у довжину з місця, см. (хлопці). Згинання і розгинання } \\
\text { рук в упорі лежачи на підлозі, разів або Стрибок у довжину з місця, см. (дівчата). } \\
\text { 2. Біг на 30, 60, } 100 \text { м, с (залежно від віку). } \\
\text { 3. Човниковий біг } 4 \text { × } 9 \text { м, с. } \\
\text { 4. Нахил тулуба вперед з положення сидячи, см. } \\
\text { 5. Біг на } 1000,1500,2000,3000 \text { м (залежно від віку і статі). }\end{array}$ \\
\hline
\end{tabular}

них джерел, контент аналіз нормативних і програмно-методичних документів, компаративний метод зіставлення та аналізу зарубіжного й вітчизняного досвіду з досліджуваної проблеми, логіко-теоретичний аналіз, історичний аналіз.

Результати дослідження та їх обговорення. Державні тести і нормативи 3 фізичної підготовленості населення були затвердженні в Україні в 1996 р. і визначалися як програмнонормативна основа вітчизняної системи фрізичного виховання, проте викликали дискусійні положення обґрунтованості, відповідності віковим нормам тощо [5]. У 2008 р. уряд скасував постанову Кабінету Міністрів України від 15 січня 1996 р. № 80 «Про державні тести і нормативи оцінки фрізичної підготовленості населення України», що позбавило змоги контролю за належними нормами фізичної підготовленості різних груп населення. Постановою Кабінету Міністрів України від 9 грудня 2015 р. № 1045 «Про затвердження Порядку проведення щорічного оцінювання фрізичної підготовленості населення України» тестування фрізичної підготовленості визначається пріоритетним завданням [10].

Ґрунтуючись на засадах тестології [7, 12, 17] і розвідок провідних спеціалістів у теорії тестів [4, 8, 17], було застосовано базові принципи вибору тестових випробувань: доступність різним віковим і статевим групам населення, інфрормативність і надійність, об'єктивність кількісної оцінки, наступність (можливість порівняння динаміки результатів залежно від вікового зрізу), спрямованість на основні рухові здібності (силу, витривалість, швидкість, гнучкість, координацію), зв'язок $з$ програмами фрізичної культури в закладах освіти, можливість виконання самостійно у до- машніх умовах, мотивація спонукання до систематичних занять фрізичними вправами для досягнення належних норм фрізичної підготовленості.

Тести для оцінювання фрізичної підготовленості учнівської молоді спрямовані на забезпечення об'єктивного контролю рівня розвитку основних фрізичних якостей: сили, витривалості, швидкості, координації, гнучкості, а також рівня оволодіння прикладними вміннями і навичками (табл. 1).

Важливим моментом, що має значення для практики, - це доступність методів, невеликий обсяг вимірюваних характеристик, їхня інфрормативність і можливість кількісної оцінки.

Рівень фрізичної підготовленості учнівської молоді визначають як високий (25-21 бал), достатній (20-16 балів), середній (15-11 балів), низький (10 балів та менше).

Огляд представлених тестових вправ для оцінювання фрізичної підготовленості не викликає сумніву в необхідності даної системи тестувань і це паралельні процеси в досвіді інших країн. Про тестування згадується і в Національній стратегії з оздоровчої рухової активності в Україні на період до 2025 р. «Рухова активність - здоровий спосіб життя - здорова нація» [9].

За даними щорічного загальноукраїнського тестування фрізичної підготовленості, у 2018 р.і за станом здоров'я було допущено лише 50,1\% учнівської та студентської молоді. Серед учнів, які брали участь у тестуванні, високий рівень фізичної підготовленості мають 27,4 \% загальної кількості осіб, які допущені до щорічного оцінювання (2017 р. - 27,4 \%), достатній - 37,4 \% (2017 р. - 36,3\%), середній - 26,0 \% (2017 р. - 26,3 \%), низький рівень - 9,2 \% відповідно (2017 р. - 10,0 \%). Отримані дані по- требують адекватних рішень і політичної рішучості для розширення механізмів впливу в даному напрямі.

Аналіз досвіду системи фрізичного виховання в КНР, зокрема досвіду практик тестування фрізичної підготовленості, дозволив виявити загальні тенденції, безумовно з урахуванням викликів часу.

За даними Xiaolu Liu, Xiaofen D. Keating, Rulan Shangguan [23], в КНР становлення системи тестування ффізичної підготовленості проходило з урахуванням історичних етапів і загальносвітових тенденцій, загалом їх було кілька: у 1954, 1975, 2007 і 2014 рр.

Китайський національний стандарт фрізичної підготовки, затверджений у 2014 р., фуннціонує сьогодні і базується на сучасних викликах суспільства, однак у ньому найменша кількість загальних тестових завдань порівняно $з$ 1954, 1975 і 2007 рр., що свідчить про скорочення кількості додаткових тестових завдань, зокрема 3 визначення прикладних навичок [22, 23].

Відповідно до стандарту (CNSPFS), загальна сума балів під час оцінювання фрізичної підготовленості становить 100 (сума балів окремих тестів, помножених на відповідні їм вагові коефріцієнти) (табл. 2).

Як стимул можуть бути зараховані додаткові бали (максимум 20), якщо діти отримають високі результати за такими тестовими завданнями: (стрибки через скакалку на час, підтягування у висі, рівномірний біг на 800 і 1000 м, піднімання тулуба в сід за $1 \mathrm{xв)}$.

Відповідно максимальна загальна оцінка ффізичної підготовленості в учнів може становити 120 балів.

Серед визначених ключових завдань у Національній програмі «Здоровий Китай 2030», розробленій уря- 
Т а б л и ц я 2. Тестові вправи для оцінювання фрізичної підготовленості школярів (Китайський національний стандарт фрізичної підготовленості)

\begin{tabular}{|c|c|c|c|}
\hline Клас & Тест & Якість & $\begin{array}{c}\text { Ваговий } \\
\text { коесфіцієнт (\%)* }\end{array}$ \\
\hline \multirow[t]{2}{*}{ Для всіх класів } & Їндекс маси тіла, ум. од & Склад тіла & 15 \\
\hline & Життєва ємність легень, мл & Аеробні можливості & 15 \\
\hline \multirow[t]{3}{*}{ 1-й, 2-й } & Біг $50 \mathrm{M}, \mathrm{C}$ & Бистрота & 20 \\
\hline & Нахил тулуба вперед з положення сидячи, см & Гнучкість & 30 \\
\hline & Стрибки через скакалку за 1 хв, разів & Координація & 20 \\
\hline \multirow[t]{4}{*}{ 3-й, 4-й } & Біг $50 \mathrm{M}, \mathrm{C}$ & Бистрота & 20 \\
\hline & Нахил тулуба вперед з положення сидячи, разів, см & Гнучкість & 20 \\
\hline & Стрибки через скакалку за 1 хв, разів & Координація & 20 \\
\hline & Підйом тулуба з положення лежачи в сід за 1 хв, разів & Сила, витривалість & 10 \\
\hline \multirow[t]{5}{*}{ 5-й, 6-й } & Біг 50 м, с & Бистрота & 20 \\
\hline & Нахил тулуба вперед з положення сидячи, см & Гнучкість & 10 \\
\hline & Стрибки через скакалку за 1 хв, разів & Координація & 10 \\
\hline & Підйом тулуба з положення лежачи в сід за 1 хв, разів & Сила, витривалість & 20 \\
\hline & Човниковий біг $8 \times 50$ м, с & Витривалість & 10 \\
\hline \multirow[t]{5}{*}{ 7-й-12-й } & Біг $50 \mathrm{M}, \mathrm{C}$ & Бистрота & 20 \\
\hline & Нахил тулуба вперед з положення сидячи, см & Гнучкість & 10 \\
\hline & Стрибок у довжину з місця, см & $\begin{array}{l}\text { Вибухова сила/швидкісно- } \\
\text { силові здібності }\end{array}$ & 10 \\
\hline & $\begin{array}{l}\text { Підтягування у висі (хлопчики) / підйом тулуба з положен- } \\
\text { ня лежачи в сід за } 1 \text { хв (дівчата), разів }\end{array}$ & Сила & 10 \\
\hline & Рівномірний біг 1000 м (хлопці) / 800 м (дівчата), хв & Витривалість & 20 \\
\hline
\end{tabular}

Примітка: *вагові коефіцієнти враховуються під час підрахунку балів і визначення загального рівня фізичної підготовленості

дом Китаю для поліпшення здоров'я населення пріоритетне місце відводиться політиці 3 удосконалення шкільного фрізичного виховання [20]. у програмі особливо підкреслюється необхідність забезпечувати школярам 60-хвилинну рухову активність на добу і ставиться мета, щоб принаймні 25 \% школярів відповідали «відмінному» рівню китайських стандартів фрізичної підготовки, а згодом домогтися того, щоб 50 \% молоді досягли «відмінних» показників фрізичної підготовленості до 2022 р. і 60 \% - до 2030 р. [15, 20].

Необхідність рішучих дій доповнюють дані масштабних перехресних і ретроспективних популяційних досліджень, які демонструють деякі разючі результати в Китаї: менше чверті (22 \%) школярів займаються будь-яким типом щоденної фрізичної активності тривалістю 60 хв або більше, відмічається тенденція до зниження загальної фрізичної активності [14].

За даними досліджень, 85,8 \% ведуть малорухливий спосіб життя, і тільки 15-34 \% дотримуються рекомендованих норми фрізичної активності, а це все веде до погіршення фізичної підготовленості $[16,19]$. Як результат, тільки троє з 10 учнів отримують оцінку «відмінно» або «добре» за національними стандартами фрізичної підготовленості [24].

Дискусія. Огляд систем тестів фізичної підготовленості учнівської молоді України і КНР визначає притаманні їм свої методологічної основи. Безперечно наявність національних систем тестування фрізичної підготовленості $€$ важливим ефектив- ним інструментом забезпечення умов для всебічного гармонійного розвитку особистості і вектора національних політик.

Наукові дослідження спрямовані, насамперед, на порівняння існуючої практики фрізичного виховання провідних світових країн 3 практикою вітчизняного фізичного виховання, що дозволить уникнути ряду можливих проблем на шляху оптимізації існуючої програмно-нормативної бази.

Отримані нами дані про системи тестування фозичної підготовленості в КНР підтверджуються в роботі Л. П. Сергієнка [11], який представив досить фрундаментальний огляд систем тестування рухових здібностей школярів різних країн.

Деякі учені [8] досліджували особливості тестування рівня фрізичної 
підготовленості школярів у середніх школах США (на прикладі штату Mіссурі) і представили цікаву інформацію про диференціацію під час оцінювання однієї якості з допомогою альтернативних тестів.

Визначені вектори національних стратегій України і КНР стосовно фрізичної підготовленості населення (Національна стратегія з оздоровчої рухової активності в Україні на період до 2025 р. «Рухова активність - здоровий спосіб життя - здорова нація», Тhe State Council. The People's Republic of China. Outline of the "Healthy China 2030» Plan) простежуються і в інших країнах. Зокрема, G. R. Tomkinson et al. [21] відзначають, що розробка національних норм і визначення національної політики щодо фрізичного виховання європейських дітей здійснюється завдяки ряду тестів Eurofit.

у 2009 р. в Європейському Союзі на базових положеннях системи Eurofit було представлено ряд тестів ALPHA-FIT (Оцінка рівнів фрізичної активності та фітнесу) для оцінювання пов'язаної зі здоров'ям фрізичної підготовленості дітей і підлітків. Тести ґрунтуються на підтвердженій прогностичній валідності взаємозв'язку фрізичної підготовленості і здоров'я, критеріях валідності і надійності використання польових тестів з фізичної підготовленості для молоді [18].

Дискусійним питанням залишається відсутність тестових вправ для оцінювання прикладних умінь і навичок дітей, проте ця тенденція спостерігається і в інших системах тестування фрізичної підготовленості.

Висновки. У системах тестування фрізичної підготовленості учнівської молоді України і КНР відображено загальні підходи до організації та фрорматування тестових нормативів, які дозволяють оцінити основні рухові якості учнів, а в досвіді практики КНР система доповнена індексом маси тіла й оцінкою фуннкціональних можливості дихальної системи. Узагальнюючи дані тестування двох країн, необхідно відзначити, що рівень фрізичної підготовленості потребує адекватної реакції в прийняті рішень уповноважених органів влади, в ключовому аспекті забезпечення самого процесу фрізич- ної підготовки (створення належних умов, інфрраструктури тощо).

Перспективи подальших досліджень передбачають вивчення наукового підґрунтя для кожної тестової вправи і об'єктивного обґрунтування величини цих нормативів для учнівської молоді, що відповідає умовам сучасного суспільства.

Конфлікт інтересів. Автори заявляють, що відсутній будь-який конфрлікт інтересів.

\section{ЛІТЕРАТУРА}

1. Ажиппо АЮ, Дорофеева ТИ, Пугач ЯИ, Артемьева ГП, Нечитайло МВ, Друзь ВА. Норма стандарты и тесты в структуре построения мо ниторинга физического развития, физической подготовленности и физического состояния Слобожанський науково-спортивний вісник 2015; 5 (49): 13-23.

2. Боднар IP, Андре АС. Тести і нормативи для експрес-контролю фізичної підготовленост і здоров'я учнів середнього шкільного віку. В Єрмаков СС, редактор. Педагогіка, психологія та медико-біологічні проблеми фрізичного вихо вання і спорту: зб. наук. праць. 2016; 4: 11-17.

3. Васьков ЮВ, Пашков ІМ. Управління фізичним вихованням в загальноосвітньому на вчальному закладі. Харків: Торсінг плюс; 2006 $192 \mathrm{c}$.

4. Годик МА, Бальсевич ВК, Тимошкин ВН Система общеевропейских тестов для оценки физического состояния человека. Теория и практика физической культуры. 1994; 5-6: 24-32.

5. Зубалій МД. Державні тести і нормати ви оцінки фізичної підготовленості населення України. Київ;1996. 36 с.

6. Круцевич Т, Трачук С. Нормативні основи сучасної системи фізичного виховання різних груп населення України. Спортивний вісник Придніпров'я. 2017; 1: 184-188.

7. Лях ВИ. Двигательные способности школьников: основы теории и методики развития. Москва: Терра-Спорт; 2000. 241 с.

8. Мандюк АБ, Чухраюк АО. Особливості тестування рівня фізичної підготовленості школярів у середніх школах США (на прикладі штату Міссурі). Слобожанський науковоспортивний вісник. 2012; 5 (2):10-13.

9. Національна стратегія 3 оздоровчо рухової активності в Україні на період до 2025 року «Рухова активність - здоровий спосіб життя - здорова нація». Режим доступу: http:// zakon2.rada.gov.ua/laws/ show/42/2016

10. Про затвердження Порядку проведення щорічного оцінювання фізичної підготовленост населення України (Постанова Кабінету Міністрів України від 9 грудня 2015 р. № 1045) Режим доступу: http://zakon3.rada.gov.ua/laws/ show/1045-2015-\%D0\%BF

11. Сергієнко ЛП. Тестування рухових здібностей школярів. Київ: Олімпійська л-ра 2001. 440 c.

12. Сергієнко ЛП. Технології наукових досліджень у фізичній культурі: підручник для студентів вищих навчальних закладів: у 2 кн Кн. 1. Тернопіль: Навчальна книга - Богдан; 2014. 496 c.
13. Сергієнко ЛП. Технології наукових досліджень у фізичній культурі: підручник для студентів вищих навчальних закладів: у 2 кн. Кн. 2. Тернопіль: Навчальна книга - Богдан 2015. 900 C.

14. Ao D, Wu F, Yun C-F, et al. Trends in physical fitness among 12-year-old children in urban and rural areas during the social transformation period in China. J Adolesc Health 2019;64:250-7. doi:10.1016/j.jadohealth.2018.08.021.

15. Central Committee of the Communist Party of China State Council of China. Healthy China 2030 Blueprint Guide. 2016. Available: http://www. gov.cn/zhengce/201610/25/content_5124174.htm

16. Fan X, Cao Z-B. Physical activity among Chinese school-aged children: national prevalence estimates from the 2016 physical activity and fitness in China-The youth study. J Sport Health Sci 2017; 6: 388-94. doi:10.1016/j.jshs.2017.09.006.

17. Krutsevich T, Pangelova N, Trachuk S Model-target characteristics of physical fitness in the system of programming sports and recreational activities with adolescents. Journal of Physical Education and Sport. 2019; 19 (1): 242-248. DOI:10.7752/jpes.2019.s1036.

18. Ruiz JR, Castro-Piñero J, EspañaRomero V, et al. Field-based fitness assessment in young people: the ALPHA health-related fitness test battery for children and adolescents. $\mathrm{Br} J$ Sports Med. 2011;45(6):518-524. doi:10.1136/ bjsm.2010.075341.

19. Song C, Gong W, Ding C, et al. Physical activity and sedentary behavior among Chinese children aged 6-17years: a cross-sectional analysis of 2010-2012 China National Nutrition and health survey. BMC Public Health. 2019;19:936 doi:10.1186/s12889-019-7259-2

20. The State Council. The People's Republic of China. Outline of the "Healthy China 2030» Plan, 2016. Available: http://www.gov.cn/ zhengce/2016-10/25/content 5124174.htm

21. Tomkinson GR et al. European normative values for physical fitness in children and adolescents aged 9-17 years: results from 2 779165 Eurofit performances representing 30 countries. British Journal of Sports Medicine. 2017 52(22):1-13 DOI: 10.1136/bjsports-2017-098253.

22. Xiaofen D Keating, Rachyl Stephenson Xiaolu Liu, Jeff Colburn. Cross-Cultural Comparison of Youth Fitness Testing in China and the US An Ecological Systems Model Approach. ICHPERSD Journal of Research. 2019; 10.2:20-27.

23. Xiaolu Liu, Xiaofen D. Keating, Rulan Shangguan. Historical Analyses of Fitness Testing of College Students in China. ICHPER-SD Journal of Research. 2017; 9.1:24-32.

24. Zhu Z, Yang Y, Kong Z, et al. Prevalence of physical fitness in Chinese school-aged children findings from the 2016 physical activity and fitness in China-The youth study. J Sport Health Sci. 2017;6:395-403. doi:10.1016/j.jshs.2017.09.003.

\section{LITERATURE}

1. Azhippo AY, Dorofeyeva TI, Pugach YI Artemyeva GP, Nechitaylo MV, Druz VA. Norm, standards and tests in the structure of designing monitoring of physical development, fitness and state. Slobozhanskyi naukovo-sport. visnyk. 2015 5 (49): 13-23.

2. Bodnar IR, Anfre AS. Tests and standards for express-control for physical fitness and health of schoolchildren. In: Iermakov SS, editor. Pedahohika, psykholohiia ta medyko-biolohichni problem fizychnoho vykhovannia i sportu: zb. nauk. ptats 2016; 4: 11-17. 
3. Vaskov IV, Pashkov IM. Managing physica education in general education institution. Kharkiv Torsing plius; 2006. 192p.

4. Godik MA,Balsevich VK, Timoshenko VN System of general European tests for human phys ical state assessment. Teoriya i praktika fizicheskoy kultury. 1994; 5-6: 24-32.

5. Zubaliy MD. State tests and standards for assessing Ukrainian population physical fitness. Kyiv;1996. 36 p.

6. Krutsevych T, Trachuk S. Standard bases of modern system of physical education of different population groups of Ukraine. Sportyvnyi visnyk Prydniprovia. 2017; 1: 184-188.

7. Liakh VI. Motor capacities of school children: bases of theory and methods of development. Moscow: Terra-Sport; 2000. 241 p.

8. Mandiuk AB, Chukhraiuk AO. Features of testing of physical fitness level in students of US secondary schools (Missouri state). Slobozhanskyl naukovo-sport. visnyk. 2012; 5 (2):10-13.

9. National Strategy for Physical Activity in Ukraine for the period up to 2025 «Physical activity - a healthy lifestyle - a healthy nation». Access mode: http://zakon2.rada.gov.ua/laws/ show/42/2016
10. On approval of the Procedure for conducting the annual assessment of physical fitness of the population of Ukraine (Resolution of the Cabinet of Ministers of Ukraine of December 9 , 2015 № 1045). Access mode: http://zakon3.rada gov.ua/laws/show/1045-2015-\%D0\%BF

11. Serhiienko LP. Testing of school children motor capacities. Kyiv: Olimpiyska literatura; 2001 $440 \mathrm{p}$.

12. Serhiienko LP. Technologies of scientific studies in physical culture: textbook for higher ed ucation institution students: in 2 books. Book 1 Ternopil: Navchalna knyha - Bohdan; 2014. 496 p.

13. Serhiienko LP. Technologies of scientific studies in physical culture: textbook for higher ed ucation institution students: in 2 books. Book 2 Ternopil: Navchalna knyha - Bohdan; 2015. 900 p.

14. Ao D, Wu F, Yun C-F, et al. Trends in physical fitness among 12-year-old children in urban and rural areas during the social transformation period in China. J Adolesc Health 2019;64:250-7. doi:10.1016/j.jadohealth.2018.08.021.

15. Central Committee of the Communist Party of China State Council of China. Healthy China 2030 Blueprint Guide. 2016. Available: http://www. gov.cn/zhengce/201610/25/content_5124174.htm

\section{ІНФОРМАЦІЯ ПРО АВТОРІВ}

Трачук Сергій Васильович https://orcid.org/0000-0002-5580-0510, trachuk_sergey@i.ua Ген Янь 995241074@qq.com

Мамедова Інна Степанівна https://orcid.org/0000-0003-1017-9369, grinchukveronika1@gmail. com

Національний університет фізичного виховання і спорту України, 03150, Київ, вул. Фізкультури, 1

\section{INFORMATION ABOUT THE AUTHORS}

Trachuk Sergii https://orcid.org/0000-0002-5580-0510, trachuk_sergey@i.ua Gen Yan995241074@qq.com Mamedova Inna https://orcid.org/0000-0003-1017-9369, grinchukveronika1@gmail.com National University of Ukraine on Physical Education and Sport, 03150, Kyiv, Fizkul'tury str., 1.
16. Fan X, Cao Z-B. Physical activity among Chinese school-aged children: national prevalence estimates from the 2016 physical activity and fitness in China-The youth study. J Sport Health Sci 2017; 6: 388-94. doi:10.1016/j.jshs.2017.09.006.

17. Krutsevich T, Pangelova N, Trachuk S. Model-target characteristics of physical fitness in the system of programming sports and recreational activities with adolescents. Journal of Physical Education and Sport. 2019; 19 (1): 242-248. DOI:10.7752/jpes.2019.s1036.

18. Ruiz JR, Castro-Piñero J, EspañaRomero V, et al. Field-based fitness assessment in young people: the ALPHA health-related fitness test battery for children and adolescents. $\mathrm{Br} J$ Sports Med. 2011;45(6):518-524. doi:10.1136/ bjsm.2010.075341.

19. Song C, Gong W, Ding C, et al. Physical activity and sedentary behavior among Chinese children aged 6-17years: a cross-sectional analysis of 2010-2012 China National Nutrition and health survey. BMC Public Health. 2019;19:936. doi:10.1186/s12889-019-7259-2.

20. The State Council. The People's Republic of China. Outline of the "Healthy China 2030» Plan, 2016. Available: http://www.gov.cn/ zhengce/2016-10/25/content 5124174.htm

21. Tomkinson GR et al. European normative values for physical fitness in children and adolescents aged 9-17 years: results from 2 779165 Eurofit performances representing 30 countries. British Journal of Sports Medicine. 2017; 52(22):1-13 DOI: 10.1136/bjsports-2017-098253.

22. Xiaofen D Keating, Rachyl Stephenson, Xiaolu Liu, Jeff Colburn. Cross-Cultural Comparison of Youth Fitness Testing in China and the US: An Ecological Systems Model Approach. ICHPERSD Journal of Research. 2019: 10.2:20-27.

23. Xiaolu Liu, Xiaofen D. Keating, Rulan Shangguan. Historical Analyses of Fitness Testing of College Students in China. ICHPER-SD Journal of Research. 2017; 9.1:24-32.

24. Zhu Z, Yang Y, Kong Z, et al. Prevalence of physical fitness in Chinese school-aged children: findings from the 2016 physical activity and fitness in China-The youth study. J Sport Health Sci. 2017;6:395-403. doi:10.1016/j.jshs.2017.09.003.

Надійшла 16.12.2020 